\title{
Antifungal activity of cow urine.
}

\author{
Dr. Sanyogita S. Deshmukh*, Shraddha S. Rajgure, Dr. Sangita P. Ingole \\ Department of Microbiology, Shri Shivaji Science College, Amravati. \\ Department of Environmental Science, Shri Shivaji Science College, Amravati.
}

\begin{abstract}
The antifungal activity of cow urine was studied. The indoor feeding cow and an outdoor grazing cow were selected for the study. The urine samples of both the cows were tested. A comparative antifungal study was done and promising results were obtained. Outdoor grazing cow that consumes variety of green grass including medicinal herbs of jungles excretes urine showing better antifungal activity, in comparison with the indoor grazing cow which consumes a limited variety of fodder.
\end{abstract}

Keyword-Antifungal activity.

\section{INTRODUCTION}

From the ancient times, cow urine has been used as a medicine. In Veda's cow urine is compared to the nector. It is one of the most effective secretions of animal origin with innumerable therapeutic values. (Cow urine manual)

The older the cow urine, the more useful it is. It doesn't decay. Cow urine contains copper and gold salt which are elixirs. Cold is capable of curing diseases. Cow urine destroys miseries and disease. It purifies both mind and body (R. kavya).As per a survey carried out by Kiwuso et. al (2004) cow urine, wood ash and red pepper are used for controlling termites. Inhibitory effect of some plant extract and cow urine on conidial germination of plant pathogen was studied by Nargis Akhtar(2006). Dalbergia sisso \& Datura stramonium in cow urine showed antibacterial properties against pathogenic gram+ \& gram- bacteria. H.Yadav (2008).

Indoor cow feed on fodder fixed for animal feeding, while outdoor grazing cow get a variety of fresh plant material to consume. This could possibly bring about a change in the composition of there urine. (It would be interesting to study comparative effect of these urine samples on fungal growth.)

Till now no appreciable data was available on antifungal activity of cow urine. Thus the present study was under taken to investigate antifungal activity of cow urine.

1) Urine Samples -

\section{MATERIAL AND METHOD}

Cow urine samples were collected from a healthy outdoor grazing cow and a healthy cow residing in cow shed in the nearby premises of Amravati city Maharashtra State of India.

2) Sabouraud glucose agar medium with chloramphenicol -

Casein enzyme hydrolysate

Peptic digest of animal tissue

Dextrose

Chloramphenicol

Agar

The test fungi are or follows -

1 Fusarium oxysporum

2 Claviceps purpurea

3 Rhizopus oligosporus

4 Aspergillus oryzae

$5 \quad$ Penicillium notatum

6 Trichoderma Viridae

7 Alternaria Solani

8 Candida albicans
$-5 \mathrm{gm} / \mathrm{lit}$.

- $5 \mathrm{gm} / \mathrm{lit}$.

- $0.05 \mathrm{gm} / \mathrm{lit}$

$40 \mathrm{gm} / \mathrm{lit}$.

- $15 \mathrm{gm} / \mathrm{lit}$

\section{TEST FUNGI}

NCIM 1008

NCIM 1046

NCIM 1215

NCIM 1212

NCIM 741

NCIM 1051

NCIM 887

NCIM 3471 
Antifungal activity of cow urine.

$9 \quad$ Aspergillus Candida

NCIM 861

The pure culture of fungi was obtained from NICM Pune, maintained on Sabouraud chloramphenicol agar medium. Culture were maintained in refrigerator for use and regularly checked for contamination. Periodic transfers were made aseptically.

Preparation of spore suspension -

1) A small aliquot of distilled water was taken in a clean test tube. The tubes were plugged properly and sterilized at $121^{\circ} \mathrm{c}$ for 15 mins. at $15 \mathrm{lbs}$ pressure.

2) After sterilization and cooling the distilled water tubes, few loopful of well sporulated fungal pure culture were transferred to the tubes containing distilled water with the help of inoculation loop.

3) The contents were mixed well and used for antifungal assay by point inoculation method.

Screening for antifungal activity -

1) SDA Medium was prepared, Poisoned with varying concentrations of urine samples of indoor and outdoor feeding cow, sterilized and dispensed into Petri plates.

2) After solidification of the medium, the test fungi were inoculated by point inoculation method under aseptic conditions.

3) The spore suspension for test fungi were taken with the help of sterile inoculation needle and inoculated by touching the center of medium without dispersing the inoculum.

4) The plates were incubated at room temperature $\left(25\right.$ to $\left.27^{0} \mathrm{c}\right)$ for 3 days.

5) After solidification, the colony diameter were measured (as per table $1 \& 2$ )

\section{RESULT AND DISCUSSION}

Table- 1: Antifungal activity of different concentrations of cow urine.(Indoor feeding cow)

Cow urine concentration in the medium: 5, 10, 15 and $20 \mathrm{ml}$ in $100 \mathrm{ml}$ medium.

\begin{tabular}{|l|c|c|c|c|c|}
\hline Test fungus & $\begin{array}{c}\text { Control } \\
\text { (C.D.) }\end{array}$ & $\begin{array}{c}5 \% \mathrm{ICU} \\
\text { (C.D.) }\end{array}$ & $\begin{array}{c}10 \% \mathrm{ICU} \\
\text { (C.D.) }\end{array}$ & $\begin{array}{c}15 \% \mathrm{ICU} \\
\text { (C.D.) }\end{array}$ & $\begin{array}{c}20 \% \mathrm{ICU} \\
\text { (C.D.) }\end{array}$ \\
\hline $\begin{array}{l}\text { Fusarium } \\
\text { oxysporum }\end{array}$ & $3.6 \mathrm{~cm}$ & $2.4 \mathrm{~cm}$ & $2.2 \mathrm{~cm}$ & $2.2 \mathrm{~cm}$ & $0.7 \mathrm{~cm}$ \\
\hline $\begin{array}{l}\text { Claviceps } \\
\text { purpurea }\end{array}$ & $1.4 \mathrm{~cm}$ & $1.0 \mathrm{~cm}$ & $0.8 \mathrm{~cm}$ & $0.8 \mathrm{~cm}$ & $0.7 \mathrm{~cm}$ \\
\hline $\begin{array}{l}\text { Rhizopus } \\
\text { oligosporus }\end{array}$ & $6.0 \mathrm{~cm}$ & $4.2 \mathrm{~cm}$ & $4.8 \mathrm{~cm}$ & $4.3 \mathrm{~cm}$ & $2.6 \mathrm{~cm}$ \\
\hline $\begin{array}{l}\text { Aspergillus } \\
\text { oryzae }\end{array}$ & $2.8 \mathrm{~cm}$ & $2.5 \mathrm{~cm}$ & $2.4 \mathrm{~cm}$ & $2.3 \mathrm{~cm}$ & $1.8 \mathrm{~cm}$ \\
\hline $\begin{array}{l}\text { Penicillium } \\
\text { notatum }\end{array}$ & $2.4 \mathrm{~cm}$ & $1.4 \mathrm{~cm}$ & $1.2 \mathrm{~cm}$ & $1.0 \mathrm{~cm}$ & No Growth \\
\hline $\begin{array}{l}\text { Trichoderma } \\
\text { viridae }\end{array}$ & $5.0 \mathrm{~cm}$ & $3.6 \mathrm{~cm}$ & $2.2 \mathrm{~cm}$ & $1.9 \mathrm{~cm}$ & No Growth \\
\hline $\begin{array}{l}\text { Alternaria } \\
\text { solani }\end{array}$ & $2.0 \mathrm{~cm}$ & $2.2 \mathrm{~cm}$ & $1.9 \mathrm{~cm}$ & $1.8 \mathrm{~cm}$ & No Growth \\
\hline $\begin{array}{l}\text { Candida } \\
\text { albicans }\end{array}$ & $0.6 \mathrm{~cm}$ & $0.4 \mathrm{~cm}$ & $0.3 \mathrm{~cm}$ & $0.3 \mathrm{~cm}$ & No Growth \\
\hline $\begin{array}{l}\text { Aspergillus } \\
\text { candidus }\end{array}$ & $2.2 \mathrm{~cm}$ & $2.1 \mathrm{~cm}$ & $1.8 \mathrm{~cm}$ & $1.7 \mathrm{~cm}$ & $1.5 \mathrm{~cm}$ \\
\hline
\end{tabular}

Table-2: Antifungal activity of different concentrations of cow urine

(Outdoor feeding cow)

\begin{tabular}{|l|l|l|l|l|l|}
\hline Test Fungus & $\begin{array}{l}\text { Control } \\
\text { (C.D) }\end{array}$ & $5 \%$ OCU(C.D & $10 \%$ OCU(C.D) & $\begin{array}{l}15 \% \text { OCU } \\
\text { (C.D.) }\end{array}$ & 20\% OCU(C.D) \\
\hline Fusarium oxysporium & $3.6 \mathrm{~cm}$ & $2 \mathrm{~cm}$ & $2.1 \mathrm{~cm}$ & $1.3 \mathrm{~cm}$ & $1 \mathrm{~cm}$ \\
\hline Claviceps purpurea & $1.4 \mathrm{~cm}$ & $1.2 \mathrm{~cm}$ & $0.8 \mathrm{~cm}$ & $0.8 \mathrm{~cm}$ & No growth \\
\hline Rhizopus oligosporius & $6 \mathrm{~cm}$ & $5 \mathrm{~cm}$ & $2.4 \mathrm{~cm}$ & $2.4 \mathrm{~cm}$ & No growth \\
\hline Aspergillus oryzae & $2.8 \mathrm{~cm}$ & $1.8 \mathrm{~cm}$ & $1.8 \mathrm{~cm}$ & $1.5 \mathrm{~cm}$ & $1.2 \mathrm{~cm}$ \\
\hline Penicillium notatum & $2.4 \mathrm{~cm}$ & $0.8 \mathrm{~cm}$ & No growth & No growth & No growth \\
\hline Trichoderma viridae & $5 \mathrm{~cm}$ & $2 \mathrm{~cm}$ & No growth & No growth & No growth \\
\hline Alternaria solanii & $2 \mathrm{~cm}$ & $0.8 \mathrm{~cm}$ & No growth & No growth & No growth \\
\hline $\begin{array}{l}\text { Candida albicans } \\
\text { Aspergillius }\end{array}$ & $0.6 \mathrm{~cm}$ & $0.6 \mathrm{~cm}$ & $0.4 \mathrm{~cm}$ & $0.3 \mathrm{~cm}$ & No growth \\
\hline candidus & $2.2 \mathrm{~cm}$ & $1.7 \mathrm{~cm}$ & $0.8 \mathrm{~cm}$ & $0.3 \mathrm{~cm}$ & No growth \\
\hline
\end{tabular}


Antifungal activity of cow urine.

Cow urine samples of indoor feeding cow and outdoor grazing cow were tested for their antifungal activity. Taking both urine samples into consideration and antifungal effect was evaulated comparatively.as per the study of H.S.Ravikumar Patil a drastic reduction in the germination of spores of pathogenic fungi was observed in presence of cow urine. Presence of antioxidant properties in cow urine distillate were observed by Dipanwita Dutta (2006)

Penicillum notatum, Trichoderma viridae and Candida albicans showed complete inhibition at $20 \%$ concentration of indoor feeding cow urine (as per table 2) but same fungi species were found to be inhibited more than $60 \%$ with just $5 \%$ concentration of outdoor grazing cow urine.

However, the growth of Claviceps purpureal, Aspergillus candidus and Rhizopus oligosporus was slowly inhibited by using $10 \%$ urine sample of indoor feeding cow where as by using $10 \%$ concentration of outdoor grazing cows urine, no growth of the same fungi was observed.

Urine samples of indoor feeding and outdoor grazing cow are compared it was observed that outdoor grazing cow urine was more effective than urine sample of indoor feeding cow, as an antifungal agent.

\section{CONCLUSION}

Thus from the above observation and results, we concluded that there is a concentration dependent activity of cow urine samples. Among the fungi tested, Pencillium notatum, Trichoderma viridae and Alternaria solani were highly inhibited.

Finally it is proved that cow urine acts as an effective antifungal agent. It can also be concluded that urine samples of outdoor feeding cow was more effective and inhibited growth of fungi more strongly as compared to indoor feeding cow urine.

\section{REFERENCS}

[1]. Achaliya, G. S., Meghre V.S., Wadodkar S. G., Dorle A. K. Antimicrobial activity

[2]. of different fractions of cow urine. Indian Journal Of Natural Products.

[3]. Akhtar Nargis, M.F.Begam, S. Alam, Shah Alam (2006); "Inhibitory effect of different plant extract, Cow dung \& cow urine on condial germination of Bipolaris sorokiniana" J. of Bio science, 14,87-92.

[4]. Chauhan R. S. (2004) Panchgavya Therapy (Cow Pathy.) "Current Status and Future Directions." The Indian Cow. 1. (1), 3-7.

[5]. Dharma K, Rathod R. Chauhan R. S., et al (2005) Panchgavya (Cow Pathy.) : An Overview. International Journal of Cow Science 1 (2), 26-29

[6]. Dipanwita Dutta, S.S.Devi, K. Krishnamurthi \& T. Chakrabarti(2006): "Anticlartogenic effect of redistilled Cow Urine distillate in human peripheral lymphocyte challenged ."

[7]. H. S. Ravikumar Patil, H. K. Makari, H. Gurumurti, S. Mukunda, T. R. Prasheeth Kekuda, O. M. Chetan, H. S. Anil Kumar (2007) Effect of cow urine on fungal spore germination. Trade Science Journals. 1, Issue 3.

[8]. Yadav H. (2008), Yadav M, Jain S., Bhardwaj A., Singh V, Prakash O., Marotta. F (2008); “Antibacterial property of Herbal preparation containing Dalbergia sissoo and Datura stromnium with cow urine against pathogenic Bacteria.” J. Immunopathological Pharmacolgy 21(4), 1013 - 20 


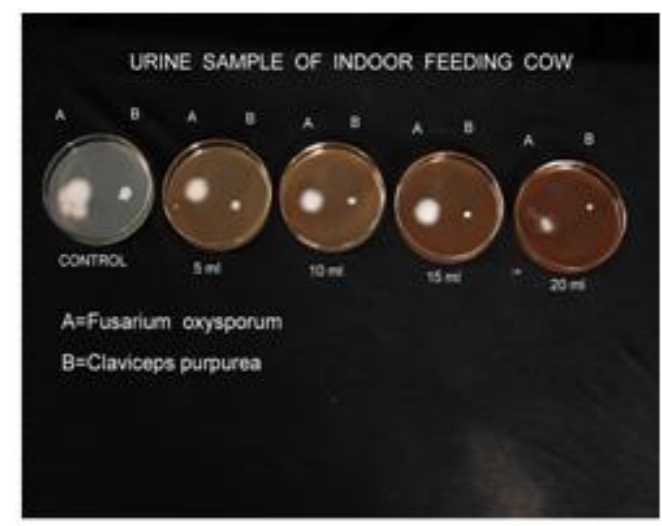

URINE SAMPLE OF OUTDOOR FEEDING COW

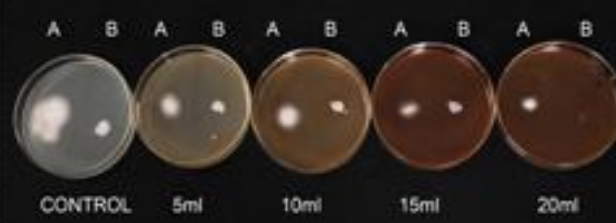

$A=$ Fusariam oxysporum

B=Claviceps purpurea
URINE SAMPLE OF INDOOR FEEDING COW

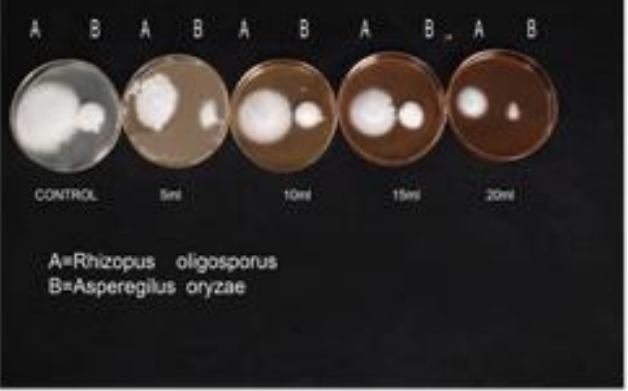

URINE SAMPLE OF OUTDOOR FEEDING COW

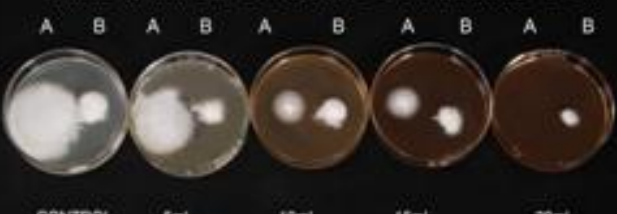

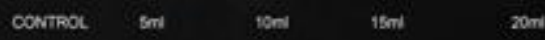

\section{A=Rhizopus olligosponus}

$B=$ Asperegilus oryzae

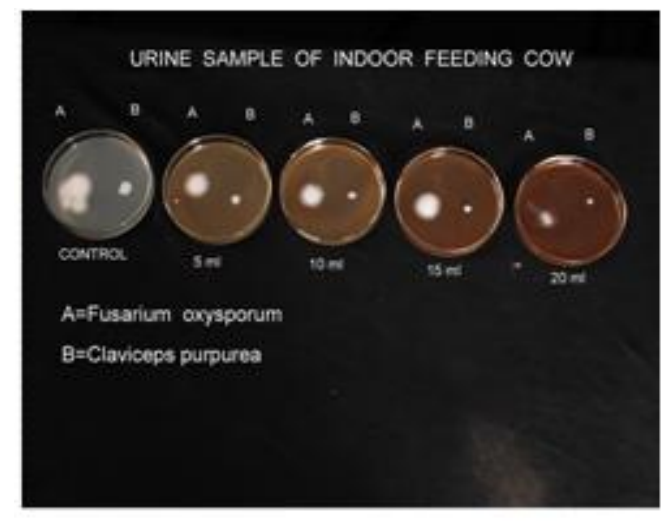

URINE SAMPLE OF OUTDOOR FEEDING COW

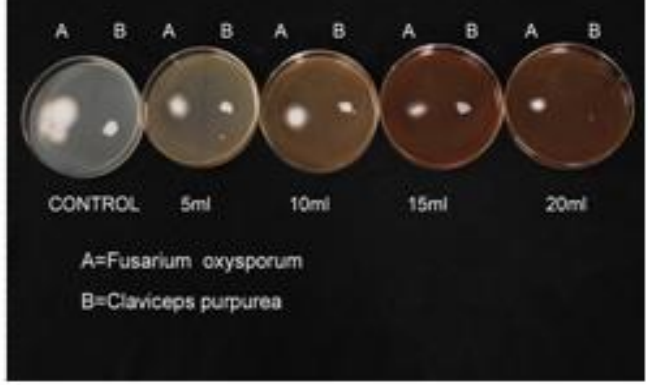

URINE SAMPLE OF INDOOR FEEDING COW

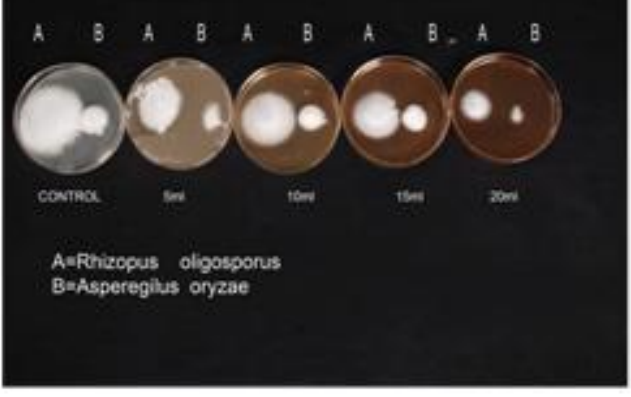

URINE SAMPLE OF OUTDOOR FEEDING COW

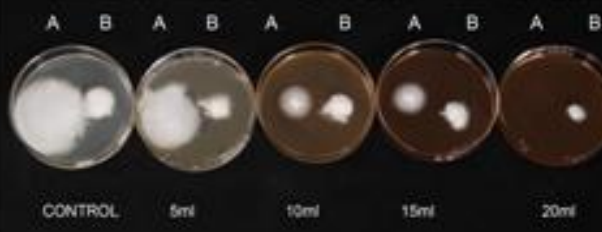

A=Rhizopus oligospons Basseregilus onyzae 